\title{
UWARUNKOWANIA PRAWNO-KULTUROWE SYTUACJI RODZINY W WYBRANYCH KRAJACH ORIENTU*
}

\author{
Karolina Mirys-Kijo**
}

\author{
CONSIDERATIONS OF THE LEGAL AND CULTURAL SITUATION \\ OF FAMILIES IN SELECTED COUNTRIES OF THE ORIENT
}

\begin{abstract}
Residents of the area known as the Orient are characterized through the prism of stereotypes operating for years. Researchers' works focus mainly on the traditions, yet omit from the analyses the legal and cultural conditions. Primarily of interest and analysis are the Muslim minorities living in Europe, instability in the Middle East and North Africa, and economic issues. Often the subject touched upon is the position of women in Islam, and the studies begin the discussion on both the West and the Arab World. The text is intended to outline situation of family and rights of each member of family, which are contained in the constitutions of the individual states, or the ones that stem from the Muslim law. For the purposes of this text, various Arab countries has been selected where the system has a different shape.
\end{abstract}

\section{- KEYWORDS}

Islam, the Islamic law, family, the Orient

* Materiały wykorzystane w pracy zostały zebrane dzięki dotacji celowej numer B1411400000662.02 przyznanej przez Wydział Filozoficzno-Historyczny Uniwersytetu Łódzkiego w 2013 roku.

** Uniwersytet Łódzki, Wydział Studiów Międzynarodowych i Politologicznych. 
To jest zgodne ze zwyczajem Boga, jak to było już przedtem; ty przecież nie znajdziesz żadnej zmiany w zwyczaju Boga

(Koran, 48:23) sura Zwycięstwo (Al-Fatah)

Powyższy cytat $\mathrm{z}$ Koranu jest jednym $\mathrm{z}$ uzasadnień sposobu tworzenia przez muzułmanów prawa tak krytykowanego na Zachodzie. Właśnie z powodu stawiania prawa boskiego ponad ludzkie religia jest obecna w każdej dziedzinie życia. Ilustruje podejście muzułmanów do wielu kwestii, w tym prawnych. Przede wszystkim zwraca uwagę na uzasadnienie jurysdykcji muzułmańskiej w dzisiejszym świecie, jak również wzbudza protesty oraz niezrozumienie wśród społeczności spoza ummy.

Mówiąc o uwarunkowaniach prawno-kulturowych rodziny w Oriencie, należy przede wszystkim zacząć od wyjaśnienia pojęcia Orientu oraz rodziny. Pozwoli to na przejście do dalszych rozważań dotyczących podjętych zagadnień, jak również na przedstawienie sytuacji rodziny na podstawie wybranych państw arabskich.

Nazwa Orient używana jest przede wszystkim do określenia państw leżących w Afryce Północnej oraz na Bliskim i Dalekim Wschodzie. W artykule natomiast zakres pojęciowy zostanie zawężony do państw arabskich, w których prawo nierozłącznie związane jest $\mathrm{z}$ wyznawaną religią - islamem. Jest to bardzo ciekawe połączenie warunkujące status rodziny, jednocześnie zaś przyczyniające się do tak ogromnego zróżnicowania w podejściu do poszczególnych gałęzi prawa. Termin Orient w odniesieniu do państw Afryki Północnej i Bliskiego Wschodu przeciętnemu człowiekowi spoza tego kręgu kulturowego kojarzy się z ciepłym klimatem, miłym wypoczynkiem, pięknymi wyrobami ze złota i srebra, przyprawami, ale i ze stereotypowymi twierdzeniami o pozbawieniu praw kobiet, opartymi na niechlubnych przykładach z codziennych doniesień medialnych. Mieszkańców obszaru zwanego Orientem charakteryzuje się przez pryzmat funkcjonujących od lat stereotypów, które ulegają stopniowym, aczkolwiek powolnym zmianom. Sam termin Orient nie został jednakże wyparty, lecz funkcjonuje po dziś dzień dla określenia chociażby potraw charakterystycznych dla wymienionych regionów, elementów garderoby i odzieży, których kształty i kolory kojarzą się z wyobrażeniami o „Magicznym Świecie Orientu” z Księgi tysiąca i jednej nocy. Główną cechą wspólną artefaktów pochodzących z trzech wymienionych obszarów jest ich określenie mianem „przedmiotów orientalnych”, do których, bez względu na realną sytuację w regionie, wielu Europejczyków ma pozytywny stosunek - szczególnie kobiety. 
Drugim istotnym z punktu widzenia artykułu zagadnieniem jest pojęcie rodziny „stanowiącej podstawową komórkę społeczną, a więc fundamentalny, konstytutywny element każdego społeczeństwa" ${ }^{1}$. W socjologii pojęcie to definiuje się jako: „mała grupa społeczna, której członkowie połączeni są małżeństwem, więzami pokrewieństwa, siecią wzajemnych zależności i stosunków społecznych, prowadzą wspólne gospodarstwo domowe oraz pełnią w niej odpowiednie role społeczne [...]"2. Ponadto rodzina uważana jest za grupę pierwotną ${ }^{3}$, a więc za najważniejszą w społeczeństwie. W związku z tym trudno nie zgodzić się ze stwierdzeniem, iż „każdy człowiek rodzi się w rodzinie, a dodatkowo przypisane są mu jasno zdefiniowane relacje. $Z$ tych określonych relacji w całym dorosłym życiu rozwijają się konkretne prawa i obowiązki, które w różnych społecznościach są różnie uwarunkowane" ${ }^{4}$. Jak widać, już dawno dostrzeżono istotę rodziny, jej znaczenie, także na gruncie arabskim. Przyjmiemy, iż sam termin rodzina będzie definiowany jako grupa osób spokrewnionych ze sobą. Struktura taka występuje w każdej społeczności, bez względu na region świata, kulturę czy status społeczny. Nie ulega także wątpliwości, iż w wielu społecznościach stanowi istotny element funkcjonowania jednostek tworzących jej strukturę ${ }^{5}$. Wśród wielu dostępnych definicji rodziny i funkcji, jakie są jej przypisywane, można wyróżnić dwie podstawowe, jakie spełnia: socjalizacja pierwotna oraz stabilizacja osobowości ${ }^{6}$. O ile pierwsze z wymienionych pojęć dotyczy procesu poznawczego otoczenia, w którym dzieci urodziły się, o tyle w drugim przypadku mamy do czynienia z emocjonalną stroną rozwoju jednostki, której rodzina udziela w tym zakresie wsparcia. Oznacza to, iż ma ona znaczny wpływ na rozwój emocjonalny najmłodszych członków grupy, zaś w późniejszym życiu odgrywa istotną rolę w utrzymaniu odpowiedniego poziomu emocjonalności wewnętrznej, która pozwala na funkcjonowanie wśród ogółu społeczeństwa.

${ }^{1}$ Rodzina, [w:] T. Szlendak, Encyklopedia socjologii, T. 3, Warszawa 2000.

2 Ibidem, s. 313.

${ }^{3}$ Jej cechą charakterystyczną jest względna trwałość, niewielka liczebność, wielofunkcyjność, jak również więź społeczna oparta na stosunkach face-to-face. Ibidem.

${ }^{4}$ C.H. Beck, Haus und Familie in Arabischen Länder. Vom Mittelalter bis zur Gegenwart, München 1991, s. 9.

${ }^{5}$ Obecnie rodzina, szczególnie w kręgach kultury zachodniej, niejednokrotnie nie odgrywa fundamentalnego znaczenia w życiu niektórych jednostek.

${ }^{6}$ Podział stworzony przez T. Parsona dla oddania charakteru i roli rodziny w społeczeństwie uprzemysłowionym. Jednakże poruszone zagadnienia dotyczą nie tylko społeczeństw zachodni, ale i społeczeństw wywodzących się z interesującego nas Orientu, o czym szerzej w dalszej części pracy. Więcej na temat wspomnianych teorii: A. Giddens, Socjologia, Warszawa 2007, s. 195. 
W przypadku społeczności arabskiej, wyznającej islam7, także rodzina w głównej mierze kształtuje osobowość człowieka i nierzadko odgrywa istotną rolę w późniejszym życiu swoich członków (co tylko potwierdza słowa Becka). Ma to silny związek z prawem muzułmańskim (powszechnie nazywanym szariatem) w znacznym stopniu determinowanym przez słowa zawarte w Koranie, które wraz z Tradycją Proroka stanowią najważniejsze źródło prawa muzułmańskiego ${ }^{8}$. Nie oznacza to, że wystarczy zapoznać się z treścią przytoczonych źródeł, aby jednoznacznie określić sytuację rodziny na terenie poszczególnych państw. Wiąże się to z ogromną różnorodnością w interpretacji Świętej Księgi islamu, a dokładnie z powstaniem szkół prawnych, które w XI wieku ostatecznie się wykształciły. Wpływ na taki stan rzeczy ma niewątpliwie specyfika języka arabskiego, w którym jedno słowo może mieć więcej niż jedno znaczenie. Doprowadza to do pewnego rodzaju wyboru, możliwości, ze strony uczonego w doborze sensu całości przekazu, a tym samym do zróżnicowania prawnego w podejściu do wielu zagadnień społecznych, także rodziny. Ostatecznym skutkiem tychże zależności jest zróżnicowanie prawa w obrębie państw arabskich, a największy wpływ na jurysdykcję oraz jurysprudencję mają zwolennicy szkoły prawnej, którzy stanowią najliczebniejszą grupę w danym państwie ${ }^{9}$.

W związku z tym należy wspomnieć o tzw. „prawie statusu osobowego/prawie osobowym"10. Choć tłumaczenie tego terminu przysparza niemało trudności, nie można go całkowicie ominąć, szczególnie kiedy mowa o zastosowaniu powyższego zagadnienia w przypadku państw arabskich. Najprościej przyjąć, że status to nic innego jak pewnego rodzaju zdolność prawna każdego człowieka. Uogólniając, możemy przyjąć na potrzeby niniejszego tekstu, iż są to określone w odpowiednich dokumentach dozwolone czynności, jakie może podjąć jednostka w zaistniałej sytuacji (np. dziecko, które stało się ofiarą molestowania, ma prawo zwrócić się o pomoc do osoby dorosłej w szkole, specjalnej organizacji czy matki i oczekiwać pomocy w rozwiązaniu swojego problemu). Naturalnie każde państwo ma własną bazę dokumentów dotyczących co można, a czego nie wolno obywatelowi. Tutaj istotnym elementem jest tło kulturowe, które bez wątpienia

${ }^{7}$ W społeczności arabskiej znaczna część to wyznawcy islamu, ale nie można zapominać o przedstawicielach innych religii.

8 Pozostałe źródła przedstawione zostaną w dalszej części pracy.

9 Za przykład może posłużyć model Królestwa Arabii Saudyjskiej lub Państwa Katar, gdzie dominuje wahhabizm.

${ }^{10}$ L.R. Sjukijajnen, Prawo muzułmańskie i ustawodawstwo rodzinne krajów arabskiego wschodu, [w:] Prawo muzutmańskie. Struktura i podstawowe instytucje, Warszawa 1990, s. 209. 
ma swoje odzwierciedlenie w aktach prawnych. Niemniej jednak w przypadku świata arabskiego wiąże się ono nierozłącznie z treścią podstawowych źródeł prawa muzułmańskiego. Faktem godnym zanotowania jest również łączenie szariatu z prawem osobowym, co ma wpływ na poszczególne gałęzie prawa ${ }^{11}$. Ponadto jako termin stosunkowo młody (po raz pierwszy użyty w 1923 roku przez sąd w Iraku ${ }^{12}$ ) w każdym państwie może się on różnić.

\section{RODZINA W KULTURZE ARABSKO-MUZUŁMAŃSKIEJ}

$\mathrm{W}$ wielu pozycjach dotyczących rodziny w świecie arabskim autorzy starają się na wstępie uzasadnić swój sposób myślenia i podejścia do pewnych kwestii. Nierzadko przedstawiają zasadność danego postępowania podyktowanego interpretacją prawa muzułmańskiego jako przeciwwagę dla wpajanych przez świat zachodni zasad jako jedynych i właściwych, a tym samym spychających na dalszy plan inne wartości. W przypadku prawa dotyczącego kwestii rodzinnych jest podobnie ${ }^{13}$. Implementacja elementów wywodzących się z prawa muzułmańskiego wzbudza wątpliwości na Zachodzie. Zaś w obrębie świata muzułmańskiego jest czymś naturalnym i niepodważalnym, gdyż Słowo, szczególnie pochodzące od Boga, nie podlega żadnym zmianom. Ponadto rodzinne prawo muzułmańskie traktowane jest jako pewnego rodzaju symbol przynależności religijnej oraz tożsamości narodowej ${ }^{14}$.W islamie nie ma możliwości oddzielenia kwestii prawnych od religijnych (czyli tak, jak życzyłaby sobie większość populacji Zachodu), tak więc stwarza to dodatkowe trudności w zrozumieniu praw rodziny $\mathrm{w}$ islamie. Przede wszystkim korzystanie z wielu źródeł przez owych uczonych muzułmańskich oraz uzasadnianie przez nich ich orzeczeń w omawianej kwestii jest wciąż kontrowersyjne dla osób spoza świata muzułmańskiego. Nie oznacza to, iż w jakikolwiek sposób zagadnienia dotyczące prawa rodzinnego w omawianej części świata są błędne lub niezasadne. Największym problemem są diametralnie różne zwyczaje kultywowane na terenach obecnego świata arabskiego, terenach Europy czy Ameryki Północnej. One to bowiem doprowadzają do kształtowania

11 The Islamic Law of Personal Status, red. J.J. Nasir, London 2002, s. 5.

12 Ibidem, s. 29.

13 L. Welchman, Women and Muslim Family Laws in Arab States: A Comparative Overview of Textual Development and Advocacy, Amsterdam 2007, s. 14.

14 Ibidem. 
się negatywnych opinii na temat praw obowiązujących w państwach omawianego regionu i obustronnego wskazywania ułomności panujących systemów.

W artykule nie będzie mowy o początkach prawa, jego kształtowaniu, historii, gdyż myślą przewodnią tekstu jest wskazanie współczesnej formy prawa rodzinnego w poszczególnych państwach ${ }^{15}$. Muzułmańskie prawo rodzinne obejmuje m.in. prawa i obowiązki małżonków, kontrakty małżeńskie, zabronione małżeństwa, alimenty dla żony, rozwiązanie małżeństwa, prawa dziecka i obowiązki rodziców względem niego ${ }^{16}$ oraz wiele innych, bardziej szczegółowych zagadnień, które mniej lub bardziej wyczerpująco zostaną tu poruszone.

Nie ulega wątpliwości, że sytuacja rodziny w państwach muzułmańskich zależy od wielu czynników. Tak jak już wspomniano, duży wpływ odgrywa religia, warunkująca sposób postępowania w określonych przypadkach mających miejsce w rodzinie. Dużą pomocą w rozstrzyganiu nieporozumień na tym tle jest fikh. Tak więc obok Księgi Matki i sunny, czyli Tradycji Proroka (źródeł pisanych) pojawiają się narzędzia ukształtowane przez jurysprudencję: idżma, kijas i ra’j17. Prawo muzułmańskie, w każdym aspekcie, jest także trudne do zrozumienia nawet dla najlepszych prawników spoza ummy, ze względu na pojawianie się wielu terminów, pojęć w ogóle nie występujących w naukach zachodnich, a które usilnie próbuje się za każdym razem porównywać ${ }^{18}$.

Islam także nie opisuje konkretnych modeli rodziny, nie określa, jak ona ma wyglądać. Dzieje się tak, gdyż w społeczeństwie muzułmańskim rodzina przybiera wielopokoleniową formę ${ }^{19}$. Wielu autorów pozycji dotyczących kwestii prawa rodzinnego w islamie wskazuje na wersety w Koranie, w których mowa

15 Na temat procesu kształtowania się prawa muzułmańskiego powstało wiele pozycji, zarówno najwybitniejszych polskich arabistów, jak i zagranicznych.

16 M.T. Mansoori, Family Law in Islam. Theory and Application, Islamabad 2009, s. VIII.

17 O ile dwa pierwsze pojęcia (zgoda uczonych i zasada analogii) angażują wielu uczonych oraz poszukują podobnych zdarzeń w pisanych źródłach, o tyle w przypadku ostatniego duże znaczenie ma indywidualne podejście sędziego muzułmańskiego.

18 Czytając pozycję W. Czaplińskiego i A. Wyrozumskiej, która jest poświęcona prawu międzynarodowemu, na myśl nasuwa się proste stwierdzenie. Łatwiej stworzyć prawo jednorodne tam, gdzie będzie ono uznawane przez organizmy państwowe bez wprowadzania przez każde z nich zmian odzwierciedlających ich indywidualne podejście. W przypadku państw arabskich często istnieją luki w dokumentach pozwalające na indywidualne podejście do różnych kwestii (sprawa wygląda podobnie w przypadku Ligii Państw Arabskich, gdzie w statucie tej organizacji zawarto sformułowanie pozwalające jej członkom na niestosowanie się do zalecenia, które uznają za niewłaściwe).

${ }^{19} \mathrm{~W}$ socjologicznej terminologii zachodniej taki model rodziny nazywa się „,rodziną rozszerzoną”. Rodzina, op.cit. 
o tym, iż członkowie nowo tworzącej się (wtedy) wspólnoty powinni „trzymać się razem" ${ }^{20}$. Ponadto owych modeli nie ma potrzeby stwarzać, gdyż są one przekazane w wymienionych powyżej źródłach.

\section{PRAWO RODZINNE A REALIA PAŃSTWOWE}

W każdym z państw arabskich system prawny kształtował się pod wpływem innych czynników, takich jak: przeszłość historyczna danego państwa, świadomość społeczeństwa czy podejście władz do kwestii religijno-prawnych.

Należy sobie zdać sprawę, że w konstytucjach wielu państw zawarte jest jasne sformułowanie, iż to na podstawie szariatu powstaje legislacja w państwie lub to on jest głównym źródłem legislacji. Bardzo trudno jest ostatecznie przeanalizować prawo rodzinne w każdym państwie z osobna. Rodzina we wszystkich wskazywana jest jako podstawa funkcjonowania społeczeństwa - i jest to fakt niezaprzeczalny. Pozostałe prawa i obowiązki w rodzinie różnią się nieznacznie.

\section{REPUBLIKA JEMENU}

Jemen, ze względu na problemy wewnętrzne i diametralnie odmienną politykę części północnej od południowej, nawet po zjednoczeniu miał problemy w ustabilizowaniu wielu kwestii. Konstytucja z 1990 roku nie zawierała sformułowań na temat szariatu lub rodziny ${ }^{21}$. W 1992 roku znowelizowano prawo państwowe dotyczące relacji rodzinnych, choć w praktyce nie było jeszcze stosowane. Dopiero w 1994 roku, po zakończeniu wojny domowej, powstała nowa konstytucja, która definiowała rodzinę jako fundament społeczeństwa i filar religii. Z kolei prawo powinno, wedle niej, strzec integralności rodziny i przyczyniać się do zacieśniania więzi pomiędzy osobami tworzącymi rodzinę ${ }^{22}$. W konstytucji z 2001 roku dodano jedynie jeden artykuł mówiący o zapewnieniu przez państwo bezpieczeństwa rodzinom osób, które utraciły życie podczas wojny, a który jest swojego rodzaju fenomenem, gdyż inne państwa arabskie przedstawiane

\footnotetext{
${ }^{20}$ Hadith on Family, red. M. Afridi, New Delhi 2008, s. 9.

${ }^{21}$ Konstytucja Republiki Jemenu, http://www.wipo.int/wipolex/en/details.jsp?id=9622, odczyt $\mathrm{z}$ dn. 20.12.2013.

22 Ibidem, art. 26.
} 
w niniejszym tekście nie posiadają podobnie skonstruowanej treści w dokumencie państwowym ${ }^{23}$.

Należy także pamiętać, iż zgodnie z art. 3 konstytucji Jemenu z 1994 i konstytucji z 2001 roku to szariat uznany jest jako źródło całej legislacji ${ }^{24}$. Wskazuje to na podporządkowanie systemu prawnego prawu muzułmańskiemu, choć obecnie sprawy dotyczące rodziny mogą być rozpatrywane przez np. sąd pierwszej instancji czy sąd najwyższy ${ }^{25}$. Mimo usilnych starań rządu, aby zmodernizować prawo obowiązujące $\mathrm{w}$ państwie, także w kwestii rodziny, nie można mówić o znacznych osiągnięciach. Nadal pełnię władzy w małżeństwie pozostawia się mężczyźnie, ale zaznacza się, że musi on szanować kobietę. Ponadto sformułowanie „kobieta jest siostrą mężczyzny. Oni mają prawa i obowiązki, które są gwarantowane i wyznaczane przez szariat i określane przez prawo" ${ }^{26}$ wcale nie ułatwia podejścia do praw i obowiązków małżonków, jak również nie nadaje więcej uprawnień kobiecie.

Prawo wyraźnie uwzględnia jemeńską kulturę i tradycję, przy jednoczesnym wprowadzeniu niewielkich zmian. I tak chociażby dopuszcza się, by małżeństwo poprzedzić dobrowolną umową między przyszłymi małżonkami, nie zaś pozostawiać całość decyzji jedynie przyszłemu mężowi. W prawie rodzinnym uwzględniono także zakaz małżeństw osób niepełnoletnich ${ }^{27}$. Zjawisko to na Zachodzie wzbudza powszechne oburzenie, gdyż informacje o dziewięcioletnich dziewczynkach, które rozwodzą się z mężem, potwierdzają wyższość przyjętych zwyczajów nad stanowionym prawem ${ }^{28}$. Jednakże obecnie pojawiają się także głosy sprzeciwu wśród samych Jemeńczyków, co być może wskazuje na powolną zmianę $\mathrm{w}$ sposobie myślenia tamtejszych społeczności. W kwestii podejścia do podmiotowości prawnej kobiety też można zauważyć zmiany. Choć to nadal

${ }^{23}$ Konstytucja Republiki Jemenu (2001), http://www.refworld.org/cgi-bin/texis/vtx/rwmain? page $=$ search $\&$ docid $=3 \mathrm{fc} 4 \mathrm{cle}$ e $4 \&$ skip $=0 \&$ query $=$ constitution $\&$ coi=YEM, odczyt $\mathrm{z}$ dn. 20.12.2013, art. 56.

24 A Comparison between Moroccan and Yemeni Family Law, Academic Seminar on December $12^{\text {th }}-16$ th, 2009 in Sana'a, Yemen, s. 15.

25 Carnegie Endowment for International Peace, http://carnegieendowment.org, odczyt z dn. 20.12.2013.

${ }^{26}$ Konstytucja Republiki Jemenu (2001), op.cit.

27 Ibidem.

28 Przed zjednoczeniem Jemenu w 1990 roku w północnej części minimalny wiek dziewczynki pozwalający zawrzeć małżeństwo to 16 lat, zaś w południowej 15 lat. W 1999 roku natomiast całkowicie zniesiono zapis w prawie państwowym dotyczący minimalnego wieku i od tej pory nie ma nakazu prawnego określającego minimalny wiek dziewczynki wstępującej w związek małżeński. 
mężczyźnie łatwiej uzyskać rozwód, to nie jest on wzbraniany kobiecie, której przysługuje prawo do rekompensaty po wprowadzonych nowelizacjach ${ }^{29}$. W przypadku rozwiedzionych małżeństw dzieci pozostają pod opieką matki, ale tylko przez określony czas (chłopiec do 9 roku życia, dziewczynka do 12) ${ }^{30}$.

\section{KRÓLESTWO ARABII SAUDYJSKIEJ}

Niewątpliwie największe państwo Półwyspu Arabskiego wzbudza wiele emocji, także ze względu na prawa w nim obowiązujące. Podobnie jak w pozostałych państwach regionu, islam jest oficjalną religią państwową, a Koran i sunna stanowią nie tylko prawo, ale pełnią rolę konstytucji. Nie jest więc zaskoczeniem, że w prawie saudyjskim nie ma określonego wieku minimalnego kobiet i mężczyzn, który uprawniałby do zawarcia związku małżeńskiego. Również w przypadku poligamii nie ma prawnie żadnego zakazu jej stosowania, skoro w głównych źródłach prawa muzułmańskiego jest to dozwolone. Kobieta nie może także sama wybrać przyszłego małżonka, gdyż zazwyczaj robi to za nią rodzina. Panna młoda bardzo często widzi swojego męża po raz pierwszy w trakcie ślubu. W przypadku rozwodu, ze względu na silnie zakorzenioną praktykę, dziecko, które ukończyło 10 rok życia, opuszcza matkę i opiekę nad nim obejmuje ojciec - szczególnie w przypadku, kiedy jest to chłopiec ${ }^{31}$. Naturalnie może także całkowicie zerwać kontakty z byłą żoną i dziećmi i nie ponosi za to społecznych konsekwencji.

Jak widać, każda dziedzina prawa podlega szariatowi, co powoduje, iż jest to jedne z najbardziej restryktywnych praw występujących w państwach arabskich. A mimo sformułowań dotyczących rodziny będącej podstawą saudyjskiego społeczeństwa ${ }^{32}$ nie można mówić o występowaniu prawa rodzinnego choć trochę zbliżonego swoją formą do znanego w Europie. Jego forma odbiega także znacznie od prawa, które funkcjonuje w pozostałych państwach Zatoki.

\footnotetext{
${ }^{29}$ Konstytucja Republiki Jemenu (2001), op.cit.

30 Republic of Yemen, http://aannaim.law.emory.edu/ifl/legal/yemen.htm, odczyt z dn. 20.12.2013.

31 A. Alkhadhari, Family Law in Saudi Arabia, Birmingham 2009, s. 6.

32 Znajduje się ono w art. 9 Praw Podstawowych stworzonych w marcu 1922 roku przez króla Fahda, które to mają pełnić funkcję konstytucji.
} 


\section{ZJEDNOCZONE EMIRATY ARABSKIE}

W przypadku Zjednoczonych Emiratów Arabskich obowiązują dwa rodzaje prawa: cywilne i szariat, przy czym sprawy dotyczące rodziny podlegają wyłącznie prawu religijnemu. Tak więc żona podlega woli swojego męża i to on decyduje o tym, co jej wolno, a co nie. O rodzinie jest mowa także w konstytucji ZEA. Już $\mathrm{w}$ art. 1 podstawowe zadania rodziny rozszerzone są o opiekę nad dziećmi i macierzyństwem. Zaleca się także sformułowanie prawa tak, by tę opiekę i troskę sprawować z uszanowaniem godności kobiety, chronić jej tożsamość oraz chronić przed pracą niezgodną z jej naturą i zdolnościami do bycia matką i żoną. W dalszej części konstytucji (art. 15) jest mowa o zagwarantowaniu przez prawo integralności rodziny oraz zapewnieniu jej bezpieczeństwa jako fundamentu społeczeństwa. Pomóc mają w tym religia, moralność i patriotyzm. Zaś w artykule następnym zawiera się potrzebę zapewnienia przez społeczeństwo opieki dla matki i dziecka oraz pomoc osobom chorym i starszym. Także w pisanych źródłach prawa muzułmańskiego występują fragmenty mówiące o zabezpieczeniu praw osób będących przedstawicielami grup wyżej wymienionych. Wskazuje to na zawarcie w konstytucji elementów wynikających z tekstów występujących w Koranie lub sunnie. Taka interpretacja prawa pozwala też na pozostawienie dziecka ojcu w przypadku rozwodu. Bardzo ważnym elementem stanowionego prawa jest fakt, iż nie we wszystkich siedmiu emiratach stosowane jest jednakowe prawo. W emiracie Dubaj dozwolone jest dochodzenie praw (w trakcie rozwodu) przez muzułmańskich małżonków niepochodzących z ZEA przed sądami religijnymi, które stosują prawa zgodne z krajem ich pochodzenia ${ }^{33}$. Sprawa wygląda podobnie w przypadku przyznawania praw do dzieci.

\section{PAŃSTWO KATAR}

W Katarze szariat jest główną wykładnią prawa ${ }^{34}$. W konstytucji także zawarta jest informacja, że „rodzina jest podstawą społeczeństwa. Katarska rodzina zaś opiera się na religii, etyce i patriotyzmie. Prawo powinno regulować odpowiednio

33 Prawo rodzinne, http://www.askexplorer.com/abu-dhabi/residents/living-in-abu-dhabi/family/ divorce\#content-section, odczyt $\mathrm{z}$ dn. 29.12.2013.

34 Konstytucja Kataru z 2004 roku, http://www.wipo.int/wipolex/en/details.jsp?id=9626, odczyt z dn. 29.12.2013, art. 1 . 
sposoby ochrony rodziny, wspieranie jej struktur i wzmacnianie jej więzi oraz ochronę macierzyństwa, dzieci i osób starszych" ${ }^{35}$. Te założenia mają swoje odzwierciedlenie w obwieszczeniu nr 22 dotyczącym prawa rodzinnego z 2006 roku $^{36}$. We wspomnianym dokumencie wyraźnie zaznaczone jest, iż główną wykładnią prawa w państwie jest szkoła hanbalicka. Jeśli dane zdarzenie nie ma wykładni prawa jej dotyczącej w tej szkole, to dany przypadek może być rozpatrywany na podstawie pozostałych szkół prawnych zaliczających się do sunnizmu. Dla niemuzułmanów dopuszcza się stosowanie w sprawach rodzinnych przepisów, które dotyczą ich w kraju pochodzenia. Katar określił także wiek osób chcących wstąpić w związek małżeński, dla mężczyzny 18 lat, kobiety 16 lat, i nie zwalnia stron z posiadania opiekuna, który ich reprezentuje i zgadza się w pełni na małżeństwo ${ }^{37}$.

Godne podziwu jest rozbudowanie prawa rodzinnego, które tworzy 301 artykułów. Regulują one zagadnienia przedstawione powyżej oraz szczegółowo określają niemalże wszystkie elementy dotyczące życia rodzinnego. Dopuszczają rozwód, także z powództwa kobiety, lecz tylko pod warunkiem przedstawienia dowodów świadczących o winie męża. Dziecko z takiego związku pozostaje pod opieką matki do 13 roku życia w przypadku syna i do 15 roku życia w przypadku córki ${ }^{38}$. Postanowienia te może zmienić jedynie sędzia, jeśli uzna, że z jakiś powodów matka nie jest w stanie odpowiednio zaopiekować się dziećmi. Jeśli rozwiedziona kobieta zdecyduje się na ponowne zamążpójście, po „okresie oczekiwania" traci możliwość opieki nad dziećmi. Szczegółowo określono także obowiązki ojca względem dzieci, czyli utrzymanie męskiego potomka, dopóki nie osiągnie wieku pozwalającego na podjęcie pracy i ożenek lub ukończenie studiów. Córką ojciec opiekować się powinien do zamążpójścia ${ }^{39}$.W porównaniu zarówno z Jemenem, ZEA, a tym bardziej z Arabią Saudyjską bez wątpienia Katar ma najlepiej rozbudowane prawo rodzinne ${ }^{40}$.

35 Konstytucja Państwa Kataru, http://www.almeezan.qa/LawPage.aspx?id=2284\&language=ar, odczyt z dn. 29.12.2013, art. 22.

36 Ibidem.

37 Ibidem, art. 17.

38 Ibidem, art. 175.

39 Ibidem.

40 Prawo dotyczy: warunków małżeństwa, zaręczyn, zakończenia małżeństwa, ogólnych warunków, charakteru małżonków, małżeństw zabronionych, reprezentowania strony żeńskiej, typów małżeństwa, praw męża i żony, zachowań w małżeństwie, wsparcia małżeńskiego oraz dzieci, dowodów na potwierdzenie ojcostwa, separacji, rozwodu z uwzględnieniem różnych jego rodzajów i wiele, wiele innych szczegółowych spraw. 


\section{KRÓLESTWO BAHRAJN}

W konstytucji z 1973 rou wyraźnie jest zaznaczone, iż to szariat jest źródłem prawa $^{41}$, zaś rodzinie poświęcono jeden artykuł mówiący, podobnie jak w ZEA czy Katarze, że rodzina jest podstawą społeczeństwa. Państwo zaś ma bronić młodzież przed zepsuciem moralnym oraz zapewnić rodzinie odpowiednie warunki do rozwoju. W żadnych dokumentach prawnych nie było jednakże konkretnych praw przypisanych członkom rodziny ponad te wynikające z Koranu i sunny, gdyż rodzina podlega jedynie prawu muzułmańskiemu. Dlatego można mówić o wielkim sukcesie w 2009 roku, kiedy to wydano obwieszczenie nr 19 dotyczące prawa rodzinnego ${ }^{42}$. Jest tam mowa o mahrze darowanym przyszłej żonie, o wyznaczeniu jego wysokości przez obie strony, jak również zawarte jest sformułowanie o podobnym wieku obydwu małżonków oraz ich równości w małżeństwie ${ }^{43}$. Kobieta ma prawo do rozwodu, dziecko zaś, w przypadku chłopca 15 lat, dziewczynka 17 lat lub do zamążpójścia, pozostaje pod opieką matki. Niewątpliwie w tej kwestii jest to znaczny postęp na tle pozostałych państw Półwyspu, choć można doszukać się nieścisłości. W 2002 roku Bahrajn podpisał Konwencje w sprawie likwidacji wszelkich form dyskryminacji kobiet z zaznaczeniem tych obszarów, w których nie będzie ona obowiązywała kobiet, m.in. w prawie rodzinnym ${ }^{44}$. W skazuje to na podporządkowanie prawa stanowionego przez państwo prawu zwyczajowemu, tradycji i praktykom, które stosowane są na tym terenie od wieków.

\section{KRÓLESTWO MAROKA}

W przypadku państw będących przez wiele lat pod panowaniem któregoś z mocarstw europejskich prawo zawiera elementy prawne swojego okupanta. W przypadku Maroka ${ }^{45}$ naturalnie mowa o Republice Francuskiej. Ówczesne mocarstwo prowadziło dość agresywną politykę mającą na celu spacyfikowanie narodu podbitego. Wprowadzono język francuski do urzędów i szkół, zabro-

\footnotetext{
41 Choć obecnie obowiązuje także prawo cywilne.

${ }^{42}$ Nie uwzględniono w niej praw kobiet reprezentujących szyizm.

43 D. Ahmed, Bahrain, New York 2010, s. 6.

44 Women's Rights in the Middle East and North Africa, red. S. Kelly, J. Breslin, Lanham 2010, s. 60.

45 Sprawa dotyczy także Algierii i Tunezji.
} 
niono sprawowania funkcji państwowych rdzennym mieszkańcom Maroka czy używano przemocy względem nich.

Głęboko zakorzeniona francuska obecność doprowadziła do tworzenia legislacji zupełnie w inny sposób, aniżeli zostało to przedstawione wcześniej. W odróżnieniu od innych państw arabskich szariat nie jest źródłem legislacji (o czym mówi konstytucja), choć art. 3 wskazuje na islam jako religię powszechnie przyjętą. Wiele uwag, także wśród przedstawicieli świata muzułmańskiego, wzbudza sformułowanie dotyczące zapewnienia przez islam wolności w praktykowaniu swojej wiary przedstawicielom innych wyznań. Wskazywać by to mogło na powolne podążanie w kierunku laicyzacji sfery prawnej i państwa w ogóle, a więc w pewnym sensie podążanie za wartościami niesionymi przez Francję. Niemniej jednak dzięki tak obranej polityce jest możliwe działanie wielu ruchów, organizacji i osób zaangażowanych w sprawy publiczne na rzecz zmian w prawie - także rodzinnym. Aby chronić rodzinę, stworzono w 2004 roku kodeks rodzinny, który składa się z 400 artykułów i reguluje szczegółowo wiele kwestii. Najważniejszymi elementami świadczącymi o początku reform jest chociażby ustalenie minimalnego wieku pozwalającego na wstąpienie w związek małżeński na 18 lat dla obu płci ${ }^{46}$ (wcześniej obowiązywał wiek 15 lat, podobnie jak w Jemenie). Kodeks jasno mówi o równym podziale własności pomiędzy małżonków, a poligamia jest niedozwolona ${ }^{47}$. Ponadto nowy kodeks dopuszcza wszczęcie postępowania rozwodowego przez kobietę i nie oznacza to bynajmniej, iż jako rozwiedziona osoba nie będzie mogła sprawować opieki nad dzieckiem. Nieposiadanie tego prawa w przypadku innych państw arabskich powodowało, iż kobiety najzwyczajniej bały się o utratę dzieci, gdyż w przeważającej liczbie przypadków sąd orzekał na korzyść małżonka. Kodeks rodzinny przewiduje także korzystniejsze prawa dla kobiet w przypadku dziedziczenia. W pozostałych elementach prawa rodzinnego szczególnie kobiety nabrały podmiotowości prawnej i wyraźnie względem prawa traktowane są na równi z mężczyznami ${ }^{48}$.

46 Marokański kodeks rodzinny 2004, Preambuła.

47 Jeśli mężczyzna chce poślubić drugą kobietę, musi o pozwolenie ubiegać się w sądzie, który po rozpoznaniu m.in. materialnej sytuacji mężczyzny podejmuje decyzję.

48 F. Harrak, The History and Significance of the New Moroccon Family Law, Evanstone 2009. 


\section{ALGIERSKA REPUBLIKA LUDOWO-DEMOKRATYCZNA}

Choć w Algierii obowiązuje francuskie prawo cywilne, to w przypadku prawa rodzinnego to szariat jest źródłem prawa. Kodeks rodzinny pojawił się po raz pierwszy w 1984 roku, zaś jego nowelizacja nastąpiła w 2005 roku. W Algierii rodzina także jest podstawą społeczeństwa ${ }^{49}$. Zgodnie $\mathrm{z}$ art. 4 stworzenie przez mężczyznę i kobietę małżeństwa służy założeniu rodziny opartej na życzliwości i obopólnym wsparciu ${ }^{50}$. Określono także wiek zawarcia związku małżeńskiego na 21 lat dla mężczyzny i 18 lat dla kobiety ${ }^{51}$. Od 2005 roku, po uzyskaniu równych praw w małżeństwie przez kobiety, obie strony wedle prawa przyczyniają się do ochrony interesów rodziny, dzieci oraz ich należytego wykształcenia ${ }^{52}$. Mimo polepszenia sytuacji kobiet nadal obowiązuje prawo, wedle którego to ojciec jest opiekunem (tzw. wali) nieletnich dzieci ${ }^{53}$. Termin ten pochodzi z Koranu ${ }^{54}$ i nie dotyczy jedynie dzieci, ale i kobiet, szczególnie mających wyjść za mąż. W nowym prawie algierskim przyszła panna młoda, jeśli ma więcej niż 19 lat, może sama wskazać, kto będzie pełnił funkcję jej opiekuna ${ }^{55}$. Także w przypadku załatwiania spraw w miejscach publicznych ograniczono opiekę męską nad kobietami. Podobnie jak w przypadku niektórych państw Zatoki Perskiej kodeks rodzinny określa także, kogo może poślubić muzułmanka, a kogo muzułmanin ${ }^{56}$. Ponadto pewnego rodzaju unowocześnieniem jest zawarcie nakazu niepozwalającego bez zgody sądu na poślubienie drugiej żony. Ma to zapewne na celu zminimalizowanie nacisku na pierwsze żony, które nierzadko musiały zgodzić się na ponowne małżeństwo swojego męża pod groźbą rozwodu. W przypadku narodzin dziecka obywatelstwo, podobnie jak w Maroku, może przejść z matki na dziecko ${ }^{57}$. Teoretycznie w przypadku rozwodu sąd przydziela opiekę nad

49 Loi no 84-11 du 9 juin 1984 portant code de la famille, JORA N² 24 du 12.06.1984, art. 2, p. 612.

50 Order No. 05-02 amending and supplementing the 1984 Family Code (18 Moharram 1426, corresponding to February 2005), http://lexalgeria.free.fr/, odczyt z dn. 30.12.2013.

51 Ibidem, s. 7.

52 Order No. 05-02 amending..., op.cit., art. 36.

53 Ibidem, art. 86.

54 Koran, sura 5:55, Stół Zastawiony, wg tłumaczenia J. Bielawskiego.

55 Carnegie Endowment for International Peace, op.cit.

56 Zgodnie z prawem muzułmańskim: muzułmanka może poślubić jedynie muzułmanina, zaś muzułmanin dodatkowo może wziąć za żonę chrześcijankę lub żydówkę.

57 M.M. Charrad, Family Law Reforms in the Arab World: Tsunisia and Morocco, New York 2012, s. 6. 
dzieckiem jednemu z rodziców, ale w praktyce w większości przypadku to wciąż mężczyznom przysługuje to prawo.

Dzięki intensywnie działającym ruchom na rzecz kobiet nadano im prawa nie tylko w kodeksie rodzinnym, ale i na innych płaszczyznach. Mimo wprowadzanych zmian widać, że nowelizacja kodeksu rodzinnego przebiega znacznie trudniej niż w Maroku. Być może Algieria nieco bardziej oddalona od Europy jest jednocześnie bardziej oporna na wprowadzanie zmian.

\section{REPUBLIKA TUNEZYJSKA}

Mimo iż prawo rodzinne opiera się na Kodeksie Napoleona, to w przypadku konfliktu prawa cywilnego z prawem muzułmańskim w kwestiach rodziny sędziowie mają prawo stosować szariat ${ }^{58}$. W art. 23 Kodeksu Statusu Osobowego Tunezji zawarte jest sformułowanie, iż oboje małżonkowie muszą spełniać obowiązki małżeńskie zgodnie ze zwyczajem i obyczajem, nakłada na męża obowiązek utrzymania rodziny wedle swoich możliwości oraz dopuszcza udział żony w utrzymaniu rodziny ${ }^{59}$. Pozostawia tym samym pewnego rodzaju możliwość interpretacji prawa, uwzględnia panujące zwyczaje oraz daje więcej możliwości kobiecie. Należy sobie zdać sprawę, że mimo wszystkich prób nowelizacji prawa rodzinnego nadal prawo zwyczajowe jest bardziej respektowane aniżeli prawo stanowione przez państwo, np. w przypadku wyjazdu nieletniego dziecka za granicę potrzebna jest zgoda ojca, choć prawo jasno określa, że jest ona niepotrzebna. Celnicy żądają jej, choć prawnie nie powinni, społeczność zaś w wielu przypadkach nie sprzeciwia się temu.

W Tunezji kobieta poniżej 20 roku życia potrzebuje opiekuna, który będzie ją reprezentował przed przyszłym mężem. Natomiast pan młody nie potrzebuje pośrednika ${ }^{60}$. Dużym osiągnięciem jest zabranie mężczyźnie prawa do rozwodu poprzez wypowiedzenie trzykrotne „rozwodzę się z tobą” (tzw. talaq). Obecnie zarówno mąż, jak i żona musi zgłosić swój zamiar do sądu, który to ma prawo orzec rozwód ${ }^{61}$. Rozwód może dokonać się na wniosek jednego z małżonków ze względu na szkodę, jaką poniósł, w przypadku obopólnej zgody lub na wniosek

\footnotetext{
58 Carnegie Endowment for International Peace, op.cit.

59 Code du Statut Personnel, http://www.jurisitetunisie.com/, odczyt z dn. 30.12.2013.

60 „Best Practices” Progressive Family Laws in Muslim Countries, August 2005, Woodrow Wilson International Center for Scholars, s. 17.

61 Ibidem, s. 19.
} 
jednej ze stron ${ }^{62}$. Jak widać, tradycyjny sposób rozwodu został zakazany, ale nie można mówić o zaprzestaniu jego stosowania. $\mathrm{W}$ wielu społecznościach, szczególnie wiejskich, jest on nadal praktykowany i akceptowany przez otoczenie.

Niewątpliwie na tle innych państw arabskich, szczególnie Półwyspu Arabskiego, Tunezja może pochwalić się wieloma zmianami i dużą otwartością. Jest państwem podchodzącym do wielu spraw dotyczących rodziny w dość nowoczesny sposób jak na kraj muzułmański. Szczególnie kwestia opieki nad dziećmi w przypadku rozwodu nie jest $\mathrm{z}$ góry przesądzona, a słowo kobiety w przypadku sprawy rozpatrywanej w sądzie jest traktowane na równi ze słowem mężczyzny. W przypadku Tunezji można więc śmiało mówić o postępie w prawodawstwie, choć zważywszy na niedawną sytuację w państwie, można przypuszczać, że jeszcze należy poczekać za nim zostaną ugruntowane reformy w zakresie kodeksu rodzinnego.

\section{ZAKOŃCZENIE}

Dysonans pomiędzy zasadami wynikającymi z prawa objawionego a prawa tworzonego przez przedstawicieli państwowych w połączeniu z ogromnym przywiązaniem do praktyk stosowanych na obszarze wpływu kultury arabskiej jest widoczny na każdym kroku. Specyfika prawa muzułmańskiego powoduje, że jest ono niezrozumiałe dla przedstawicieli spoza arabskiego kręgu kulturowego. Jest ono respektowane i uznawane dobrowolnie przez społeczności muzułmańskie, a osoby je reprezentujące traktowane są z najwyższym szacunkiem oraz respektem. Duże znaczenie bowiem ma także bojaźn przed gniewem bożym w razie zanegowania przez obywatela tego, co przecież przekazał Najwyższy. Całe prawo jest w dużej mierze interpretacją tekstów sakralnych oraz tradycjami, zwyczajami, które od wieków są kultywowane w różnych zakątkach świata muzułmańskiego.

Od dłuższego czasu pojawiają się pytania dotyczące zmian, jakie można by wprowadzić do prawa w państwach arabskich, aby uwzględnić te elementy, które nie były brane pod uwagę przy wcześniejszym jego tworzeniu. Naturalnie nowelizacja niektórych jego aspektów i wprowadzenie nowo pojawiających się zagadnien ${ }^{63}$ wysuwane są przede wszystkim przez osoby zamieszkujące państwa

${ }^{62}$ Code $d u \ldots$, op.cit.

63 Mowa tutaj przede wszystkim o pojawiającej się kwestii równości płci, praw kobiet w rodzinie lub w stosunku do przemocy, dziedziczenie etc. 
Starego i Nowego Kontynentu. Zauważają one wpływ rodzimych praktyk oraz polityki poszczególnych państw na kształtowanie się prawa rodzinnego. Wiele organizacji zagranicznych, jak również niektórzy mieszkańcy państw, których zagadnienia związane $\mathrm{z}$ kwestiami rodziny dotyczą, próbują wpłynąć na nowelizacje poszczególnych ustaw, dekretów.

Nie ulega wątpliwości, że w arabskiej części świata rodzina jest teoretycznie najistotniejszym ogniwem spajającym członków, jest centrum społeczeństwa (Koran, sura Bizantyjczycy [Ar- Rum] 30:31), rezultatem małżeństwa. Jednakże wiele wskazuje na przedmiotowe traktowanie niektórych członków rodziny, $\mathrm{w}$ tym kobiet, co podważa sens przekazywanych w dokumentach poszczególnych państw treści. Kwestia opieki nad dziećmi oraz panująca wyższość pozycji mężczyzny w decydowaniu o losie potomstwa oraz żony wciąż nie są rozwiązane. Jednocześnie zmiany, które zachodzą w prawie poszczególnych państw arabskich, pokazują chęć ze strony rodzimych rządów do przystosowania przepisów wewnętrznych do ogólnie przyjętych definicji pojęć w terminologii międzynarodowej. Godna podziwu jest umiejętność, z jaką głowy państw dostosowują te zewnętrzne kryteria tak, by nie naruszały praw nadanych przez Boga, a tożsamość i wiara pozostały bez zmian. 